KHAZANAH MULTIDISIPLIN

VOL 2 NO 22021

https://journal.uinsgd.ac.id/index.php/kl

\title{
PENERAPAN ASAS KETERBUKAAN DALAM PROSES PEMBUATAN UNDANG-UNDANG OMNIBUS LAW
}

\author{
Dirman Nurjaman \\ Ilmu Hukum, Pasca Sarjana UIN Sunan Gunung Djati Bandung, Indonesia \\ Email:dirman2295@gmail.com
}

Diterima : 1 Mei 2021, Revisi : 20 Mei 201 Disetujui : 5 Juni 2021

\begin{abstract}
This paper is to explain the principles of forming good laws and regulations so that they can be used as guidelines in any legislative formation. The application of the principles, especially the principle of openness, is the most important part that must be carried out so that the public understands the purpose of the formation of this Omnibus Law, so as to prevent polemics and rejection in the community. The research method is using a normative legal approach, meaning that the author here emphasizes more on literature study.

Keywords: Principle of openness, Omnibus Law
\end{abstract}

\begin{abstract}
ABSTRAK
Tulisan ini untuk menjelaskan landasan dan asas-asas pembentukan peraturan perundang-undangan yang baik agar dapat dijadikan pedoman dalam setiap pembentukan perundang-undangan. Penerapan asas-asas terutama asas keterbukaan menjadi bagian terpenting harus dilaksanakan agar masyarakat paham maksud daripada pembentukan undang-undang Omnibus Law ini, sehingga mencegah terjadinya polemik dan penolakan dimasyarakat. Metode penelitian yaitu menggunakan pendekatan yuridis normatif, artinya penulis disini lebih menekankan kepada studi literatur.

Kata Kunci: Asas keterbukaan, Undang-Undang Omnibus Law
\end{abstract}

\section{PENDAHULUAN}

Omnibus Law merupakan konsep yang menggabungkan secara resmi atau perubahan peraturan perundang-undangan menjadi satu bentuk Undang-Undang yang baru dengan tujuan untuk mengatasi tumpang tindih regulasi dan juga memangkas masalah dalam birokrasi yang dianggap atau sudah terbukti menghambat pelaksanaan kebijakan yang diperlukan (Anggono, 2020). Dengan demikian, setidaknya ada tiga manfaat dari penerbitan Omnibus Law adalah, menghilangkan tumpang tindih antar peraturan perundang-undangan dan juga dengan adanya Undang-Undang Omnibus Law dianggap bisa menghilangkan ego sektoral yang terkandung di dalam berbagai peraturan perundang-undangan (Sodik, 2020). Jika melihat dari konsep dan tujuan pembentukan undang-undang Omnibus 
Law suatu hal yang dirasa tepat bagi pemerintah mengambil keputusan tersebut.

Keinginan yang menjadi tujuan dalam meralisasikan sebuah konsepsi negara hukum yang bisa dikatakan demokratis yang harus memberi kesejahteraan rakyat menempatkan pemerintah selaku pihak yang bukan hanya dibebani kewajiban untuk mengupayakan kesejahteraan bagi warga negara, tetapi juga pihak yang senantiasa harus memperhatikan apa yang menjadi aspirasi rakyat. Disamping itu pemerintah harus berpedoman terhadap peraturan yang berlaku. Jadi peran pemerintah mempunyai batasan kurang lebih ada tiga hal yaitu hukum, aspirasi rakyat, dan kesejahteraan warga negara. Tiga Batasan tersebut kemudian yang dijadikan acuan pemerintah dalam setiap proses pelaksanaan tugas dan perannya. Seperti dalam proses pembentukan paraturan perundangundangan walaupun pada dasarnya dilakukan oleh lembaga yang berwenang yaitu DPR sebagai perwakilan rakyat dan sacara formal dianggap sebagai wujud konkrit aspirasi rakyat (Handoyo, 2021), tetapi pada kenyataannya tidak selalu mencerminkan dan menjawab apa yang di inginkan dan di harapkan rakyat ketika sudah dirumuskan kedalam bentuk undang-undang. Seperti pembentukan undang-undang Omnibus Law, jika melihat daripada tujuan pemerintah diawal yang dirasa baik untuk kepentingan rakyat dan harus dilakukan tetapi nyatanya respon masyarakat justru menuai banyak polemik dan penolakan. Itu artinya persepsi masyarakat tidak selamanya sama dengan tujuan yang dirasa baik menurut pemerintah dan DPR.

Pembentukan udang-undang Omnibus Law banyak menuai pelemik dan penolakan dari masyarakat hal tersebut dapat dimungkinkan sama penyebabnya karena tidak ada keterbukaan publik dan masyarakat merasa tidak dipintai aspirasinya (Fatanen, 2021). Seharusnya ada keterbukaan dalam proses pembentukan undang-undang Omnibus Law tersebut, baik dari sejak awal pembuatan hingga saat sudah di sahkan dalam bentuk fisik undang-undang Omnibus Law. Kenyataannya di berbagai situs resmi 
pemerintah dan DPR tidak ada yang mempublis draf rancangan undangundang Omnibus Law tersebut. Dengan tidak adanya draf undang-undang Omnibus Law yang dipublis di berbagai situs Pemerintah dan DPR akhirnya banyak yang berasumsi bahwa penyusunan regulasi hanya melibatkan segelintir elite kepala daerah dan asosiasi pengusaha saja. Sehingga wajar dari berbagai kalangan masyarakat banyak yang merasa tidak dilibatkan dalam pembentukannya yang terkesan diam-diam dan tidak menerapkan asas keterbukaan.

Asas keterbukan merupakan syarat yang harus terpenuhi ketika pemerintah dan DPR membentuk suatu Undang-Undang. Supaya tidak muncul banyak opini-opini di masyarakat yang tidak setuju dengan undang-undang Omnibus Law. Munculnya opini-opini dimasyarakat tidak lain disebabkan karena dalam pembuatan undang-undang Omnibus Law tersebut dianggap tidak melibatkan banyak pihak, padahal sudah jelas dalam Undang-Undang Nomor 12 Tahun 2011 Tentang Pembentukan Peraturan Peraturan-Perundangan Pasal 5 salah satu poinnya terdapat asas keterbukaan yang menjelaskan bahwa dalam pembentukan peraturan perundang-undangan mulai dari perencanaan, persiapan, penyusunan, dan pembahasan bersifat transparan dan terbuka. Pasal 5 undang-undang nomor 12 tahun 2012 tersebut selanjutnya dipertegas lewat Pasal 170 Peraturan Presiden Nomor 87 Tahun 2014 bahwa Pemerintah dan DPR harus menyebarluaskan rancangan Undang-Undang sejak tahap penyusunan.

\section{METODE PENELITIAN}

Metodelogi untuk menganalisa dalam penelitian ini adalah pendekatan yuridis normatif (Qamar et al., 2017), artinya penulisan disini lebih menekankan kepada studi literatur dimana mengkaji dengan menggunakan berbagai data skunder terdiri dari bahan-bahan yang bersumber dari perundang-undangan, teori-teori hukum, maupun pendapat para ahli secara ilmiah dan sistematis dalam mengkaji landasan dan asas dalam pembentukan peraturan perundang-undangan. 
KHAZANAH MULTIDISIPLIN

VOL 2 NO 22021

https://journal.uinsgd.ac.id/index.php/kl

\section{HASIL DAN PEMBAHASAN}

\section{Landasan dan Asas-Asas Pembentukan Peraturan Perundang-}

\section{Undangan yang Baik}

Peraturan perundang-undangan dapat dikatakan baik jika memenuhi sekurang-kurangnya tiga landasan yaitu, landasan filosofis, landasan sosiologis dan landasan yuridis. Ada juga yang menambahkan yaitu landasan politis yaitu garis kebijaksanaan politik yang menjadi dasar dalam mengarahkan ketatalaksanaan pemerintahan negara. Peraturan perundang-undangan yang tidak baik dapat juga terjadi karena tidak mempunyai landasan yang jelas (Barlian, 2016).

Memahami pengertian asas-asas hukum sangat beragam, tergantung pengertian yang di anut oleh setiap penulis yang bersangkutan (Atmadja, 2018). Seperti pendapat Paul Scholten, mengartikan bahwa asas-asas hukum itu adalah tendensi-tendensi yang disyaratkan kepada hukum. Dipahami juga bahwa asas-asas hukum merupakan pikiran-pikiran dasar yang terdapat didalam dan dibelakang sistem hukum (Bruggink, 1999). Asas-asas pembentukan peraturan perundang-undangan diartikan juga sebagai suatu pedoman atau suatu rambu-rambu dalam pembentukan peraturan perundang-undangan yang baik. Dengan adanya asas-asas untuk menjadi pedoman atau rambu-rambu yang akan mengontrol dan mengarahkan pembentukan atau pembuatan undang-undang sebagaimana seharusnya yaitu tidak hanya terdapat muatan kepentingan elite kelompok tertentu saja (Attamimi, 1990). Memang ada wewenang untuk pemerintah dan DPR yang dijamin oleh konstitusi untuk bersama-sama membentuk peraturan perundang-undangan, tetapi untuk membuat pertimbangan tetap saja harus melalui proses dan mekanisme berdasarkan hukum, juga harus terlepas dari pengaruh kelompok dan kekuatan politik ataupun keinginan pribadi masing-masing. Artinya kewenangan yang dimaksud berkewajiban menegakan hukum dan keadilan bagi seluruh aspirasi masyarakat.

Dari pemaparan di atas maka perlu kemudian dalam merumuskan 
atau mebentuk suatu paraturan mengacu kepada undang-undang nomor 12 tahun 2011 tentang tata cara pembentukan peraturan perundang-undangan yang didalamnya terdapat ketentuan-ketentuan, mulai dari proses perencanaan, persiapan, teknik penyusunan, perumusan, pembahasan, pengesahan, pengundangan dan penyebarluasan. Jadi peraturan perundang-undangan ialah setiap putusan yang tertulis dan dibuat, ditetapkan dan dikeluarkan oleh lembaga dan atau pejabat negara yang mempunyai fungsi legislasi sesuai dengan tata cara yang berlaku (Solihah and Witianti, 2016).

Dalam undang-undang nomor 12 tahun 2011 terdapat Asas-asas yang dijadikan rujukan formal dalam proses pembentukan peraturan perundang-undangan khususnya pasal 5 meliputi (Attamimi, 1990). Pertama, Asas kejelasan tujuan. Kedua, Asas kelembagaan atau organ pembentuk. Ketiga, Asas kesesuaian antara jenis dan materi. Keempat, Asas dapat dilaksanakan. Kelima, Asas kedayagunaan dan kehasilgunaan. Keenam, Asas kejelasan rumusan. Ketujuh, Asas keterbukaan yang mana proses pembentukan peraturan perundang-undangan mulai dari perencanaan, persiapan, penyusunan, dan pembahasan harus bersifat transparan dan terbuka. Dengan demikian seluruh lapisan masyarakat harus mempunyai kesempatan yang seluas-luasnya untuk dapat memberikan masukan dalam proses pembentukan peraturan perundangundangan.

Sedangkan asas-asas materil antara lain meliputi asas tentang terminilogi dan sistematika yang benar, asas dapat dikenali, asas perlakukan yang sama di hadapan hukum, asas kepastian hukum, dan asas pelaksanaan hukum sesuai dengan keadaan individual (Febriansyah, 2016).

Sementara itu, asas-asas yang harus dikandung dalam materi muatan peraturan perundang-undangan di Indonesia dirumuskan juga dalam pasal 6 sebagai berikut: Pertama, Asas pengayoman, kedua Asas kemanusiaan, ketiga Asas kebangsaan, keempat Asas kekeluargaan, kelima Asas kenusantaraan, keenam Asas bhineka tunggal ika, ketujuh Asas 
keadilan, kedelapan Asas kesamaan kedudukan dalam hukum dan pemerintahan, kesembilan Asas ketertiban dan kepastian hukum, dan kesepuluh Asas keseimbangan, keserasian, dan keselarasan. Undangundang yang baik adalah terpenuhinya syarat yang menjadi dasar dalam pembentukan undang-undang tersebut, dan undang-undang yang baik adalah yang dapat diterima oleh seluruh lapisan masyarakat.

Dalam pembentukan peraturan perundang-undangan perlu berpedoman kepada asas-asas pembentukan peraturan yang baik dan ideal. Hal ini dimaksudkan agar terhindar dari kesalahan dan kecacatan dalam pembentukan norma. Van Eikema menyatakan, bahwa asas hukum itu perlu dipandang sebagai dasar-dasar hukum, atau petunjuk-petunjuk bagi hukum yang berlaku. Pembentukan hukum perlu berorientasi pada asasasas hukum tersebut (Mas, 2014). Artinya bahwa asas hukum adalah dasardasar atau petunjuk arah dalam pembentukan hukum positif yang harus diterapkan.

Sementara, menurut Allot ada empat syarat dari suatu peraturan perundang-undangan yang baik dan dapat berlaku secara efektif yaitu, satu ada survey pendahuluan yang memadai (adequate preliminary suvey). Dua adanya komunikasi termasuk sosialisasi (communication). Tiga ada penerimaan dari warga masyarakat (acceptance). Empat melalui mekanisme penegakan hukum (Mas, 2014). Dari ke empat syarat tersebut dapat dipahami bahwa dalam membentuk suatu undang-undang harus melalui mekanisme hukum yang jelas, dan melibatkan seluruh lapisan masyarakat sebagai bentuk keterbukaan atau tranparansi.

\section{Pentingnya Penerapan Asas Keterbukaan dalam Pembuatan Undang-Undang Omnibus Law}

Polemik setelah di sahkannya undang-undang Omnibus Law jika menilai dengan kacamata pembentukan peraturan perundang-undangan menandakan adanya kecacatan legal formil dalam proses pembuatan Undang-Undang tersebut. sebagaimana dijelaskan diawal munculnya opini 
dimasyarakat yang merasa tidak dilibatkan karena tidak ada keterbukaan. Disini penulis fokus terhadap ketidakterbukaan DPR dan Pemerintah dalam proses pembuatan undang-undang Omnibus Law. Pentingnya penerapan asas keterbukaan supaya hukum mampu menkomunikasikan suatu nilai-nilai yang tertutup didalam masyarakat melalui kaidahkaidahnya, sehingga warga masyarakat dapat memahami, menghayati dan kemudian mematuhinya (Mas, 2014).

Terdapat pada Pasal 5 Undang-Undang Nomor 12 Tahun 2011 merupakan pedoman dalam setiap proses pembuatan Undang-Undang, salah satu poinnya menyebutkan asas keterbukaan. Kemudian yang dipertegas lewat Pasal 170 Peraturan Presiden Nomor 87 Tahun 2014 bahwa Pemerintah dan DPR harus menyebarluaskan rancangan UndangUndang sejak tahap penyusunan, tapi nyatanya tidak dilakukan.

Penerapan asas-asas dalam proses pembuatan peraturan perundang-undangan merupakak hal yang penting untuk dilaksanakan. Mengenai pembentukan peraturan perundang-undangan yang baik di Indonesia yang patut adalah, pertama cita hukum Indonesia yang tidak lain adalah Pancasila sebagai ide, pemandu dan norma fundamental negara. Kedua, asas negara berdasarkan hukum yang menempatkan undangundang sebagai alat pengaturan yang khas berada dalam keutamaan hukum (der Primat des Rechts). Ketiga, asas pemerintahan yang berdasarkan konstitusi yang menempatkan undang-undang sebagai dasar dan batas penyelenggaraan kegiatan-kegiatan pemerintahan (Attamimi, 1990). Yang dimaksud dengan pemerintahan adalah tiga kekuasaan eksekutif, legislatif dan yudikatif.

Undang-Undang Nomor 12 Tahun 2011 Tentang Pembentukan Peraturan Perundang-Undangan sebagai pedoman pemerintah dalam membuat Undang-Undang, sehingga perlu dijadikan rujukan atau pedoman disetiap proses pembuatan Undang-Undang sebagaimana negara Indonesia merupakan negara hukum dan pemerintahan berdasarkan konstitusi. Secara konseptuan hanya peraturan perundang-undangan yang 
menjadi sendi utama dalam pembentukan hukum, yurisprudensi tidak disebut-sebut sebagai salah satu prioritas dalam upaya pembentukan hukum nasional (Nugroho, 2014).

Dalam UUD 1945 menegaskan bahwa kedaulatan berada ditangan rakyat. Teori kedaulatan rakyat berpandangan bahwa kekuasaan tertinggi disuatu negara berada pada tangan rakyat, bukan pada tuhan, raja, maupun negara. Rakyat merupakan sumber kekuasaan negara (Assiddiqie, 2014). Kedaulatan rakyat juga tidak hanya diidentikan dengan demokrasi, tetapi mengandung nilai-nilai batiniah yang dimiliki bangsa Indonesia, yakni musyawarah (Bahri, 2017). Dengan demikian pemerintah dan DPR dalam hal ini membuat undang-undang Onibus Law seharusnya melibatkan seluruh stakeholder, dengan mengedepankan asas keterbukaan dari awal proses pembuatan hingga akhir, supaya masyarakat dapat menilai dan memantau selama proses pembuatannya sampai bisa di undangkan. Tidak baik bagi seorang pembuat undang-undang atau hukum sekaligus melaksanakannya, atau badan rakyat yang membalikan perhatian dari tujuan umum dan mengabdikan kepada pengabdian khusus. Tidak ada yang lebih berbahaya dari pengaruh kepentingan pribadi dalam urusan publik, dan penyalahgunaan hukum oleh pemerintah merupakan suatu kejahatan (Gani, 2017).

Sebagaimana diketahui bersama bahwa Indonesia merupakan negara demokrasi yang artinya dari rakyat, oleh rakyat dan untuk rakyat. Maka keterbukaan dalam pembentukan peraturan perundang-undangan merupakan syarat lahirnya suatu pemerintahan yang demokratis. Dalam negara yang berdasarkan hukum dengan sistem demokrasi keterbukaan merupakan jaminan yang seharusnya ada atau sebagai conditio sine quanon, artinya bukan sesuatu hal yang muncul secara kebetulan. Keterbukaan menjadi sesuatu hal yang sangat penting artinya untuk terselenggaranya pemerintahan yang baik dan demokratis. Dapat dikatakan juga bahwa keterbukaan merupakan prinsip ketatanegaraan untuk terciptanya kekuasaan yang baik. 
Negara yang berdasarkan hukum dan hukum yang dibentuk harus sebanyak mungkin menampung aspirasi rakyat. Kehadiran lembaga negara Dewan Perwakilan Rakyat (DPR) sebagai perwakilan rakyat diparlemen sepertinya masih memerlukan instrument lain sebagai penopang untuk lahirnya pemerintahan yang ideal, artinya tidak bisa hanya mengandalkan perwakilan rakyat yang ada di DPR saja yang notabene juga mewakili kepentingan partainya. Jadi masyarakat selain sumber aspirasi juga sebagai intrumen pengawas yang berhak menilai baik buruk, salah benar pemerintah dan DPR dalam membentuk peraturan perundang-undangan Omnibus Law.

Dalam pembentukan peraturan perundang-undangan Omnibus Law bukan hal yang mudah dan tentu akan berbeda dengan pembentukan Undang-Undang seperti pada umumnya, karena undang-undang Omnibus Law ini menggabungkan banyak undang-undang yaitu 79 Undang-Undang kedalam satu undang-undang Omnibus Law. Artinya dalam undangundang tersebut banyak mengatur kepentingan, sehingga kemudian dapat dipahami sesuatu hal yang wajar jika dimasyarakat menimbulkan banyak kecemasan. Ditambah lagi dalam proses pembentukannya tidak mengedepankan transparansi, sehingga bisa dikatakan melanggar asas keterbukaan. Artinya bertentangan juga dengan kedaulatan rakyat dalam sistem demokrasi di Indonesia.

Penyederhanaan Undang-Undang itu memang penting, tetapi jangan sampai inkonstitusional. Politik itu dinamis tetapi harus menjaga mandat rakyat yang dipilih melalui pemilu, karena rakyat memilih seluruh DPR untuk mewakili kepentingannya. Kekuasaan tertinggi ada pada rakyat, jangan sampai eksekutif mengatur kekuasaan sesukanya. Kemudian DPR harus mencerminkan jati diri rakyat karena pemegang kekuasaan dalam pembentukan peraturan perundang-undangan sesungguhnya ada pada DPR sebagai mandataris rakyat.

Negara-Negara yang Menerapkan Undang-Undang Omnibus 
KHAZANAH MULTIDISIPLIN

VOL 2 NO 22021

https://journal.uinsgd.ac.id/index.php/kl

\section{Law}

Omnibus Law dikenal juga dengan Undang-Undang sapu jagad kenapa demikian karena Undang-Undang tersebut dibuat untuk merampingkan dan menyederhanakan berbagai regulasi dengan tujuan agar tepat sasaran. Sebagaimana sudah disebutkan juga di awal Omnibus Law itu mengubah puluhan Undang-Undang yang dinilai menghambat investasi, termasuk di antaranya Undang-Undang ketenagakerjaan.

Indonesia yang merupakan negara hukum dengan menganut sistem hukum campuran dengan sistem utamanya adalah sistem eropa kontinental karena Indonesia terdiri dari berbagai suku, ras, golongan, agama dan budaya terlepas dari adanya Asas Konkordansi yang merupakan asas yang melandasi diberlakukannya hukum eropa atau hukum negeri belanda pada masa itu untuk kemudian diberlakukan kepada golongan di Hindia Belanda (Arham and Saleh, 2019).

Sebagaimana pendapat Ahli Hukum Tata Negara yaitu Jimmy Z Usufufan menurutnya konsep Omnibus Law bisa di terapkan di Indonesia karena menganut Sistem Civil Law, lanjutnya berpendapat bahwa persoalan konflik penyelenggaraan pemerintahan, saat ingin melakukan inovasi atau kebijakan yang kemudian berbenturan dengan peraturan perundang-undangan. Sehingga konsep Omnibus Law bisa menjadi salah satu jalan keluar yang mungkin bisa di ambil oleh pemerintah. Tetapi juga Omnibus Law haruslah di lakukan dalam tingkatan Undang-Undang. Meski Indonesia menganut sistem civil law.

Omnibus Law bisa digunakan di Indonesia untuk penyerangan kebijakan pusat dan daerah dalam menunjang iklim investasi. Berkenaan dengan hal tersebut, Omnibus Law bisa menjadi cara singkat sebagai solusi peraturan perundang-undangan yang saling berbenturan baik secara Vertikal maupun secara Hoarizontal.

Dengan melihat pendapat Ahli di atas penulis berpandangan bahwa sebenarnya hal pertama yang harus diperhatikan oleh pemerintah adalah bagaiman proses pembuatannya jangan sampai kemudian niat baik 
menimbulkan persepsi dan konplik di masyarakat. Seperti yang terjadi dalam proses pembuatan Omnibus Law ini yang menimbulkan persipsi negativ dan kecurigaan di masyarakat karena dianggap tidak mengedepankan asas keterbukaan.

Selain Indonesia ada 5 negara yang yang menerapkan Omnibus Law pertama yaitu negara Irlandia yang merampingkan peraturan perundangundangan hanya lewat satu Undang-Undang Omnibus Law dengan menghapus sekitar 3.225 Undang-Undang. Kedua Kanada yang memakai pendekatan Omnibus Law untuk mengimplementasikan perjanjian perdagangan Internasional dengan memodifikasi 23 Undang-Undang yang telah lama untuk dapat tunduk kepada peraturan WTO. Ketiga negara Turki juga menerapkan Omnibus Law untuk mengamandemen peraturan pajaknya. Empat negara Selandia Baru menerapkan Omnibus Law sama seperti Turki yakni untuk mengamandemen peraturan yang berkaitan dengan perpajakan. Kelima negara yang juga menerapkan Omnibus Law yaitu Filipina yang konteknya ada kesamaan dengan di Indonesia, yaitu dalam hal Investasi. Serangkaian peraturan yang memberikan insentif komprehensif, baik fiskal maupun non fiskal yang dipertimbangkan oleh pemerintah Pilifina dalam rangka pembangunan nasioanl. Dalam prosesnya dari 5 negara yang menerapkan Undang-Undang Omnibus Law mempunyai alasannya masing-masing, hanya yang menjadi sorotan yaitu terkhusus di Indonesia terkait proses pembentukannya yang terkesan diam-diam tanpa mengedepankan asas keterbukan sehingga menimbulkan kecurigaan di masyarakat. Dalam pembentukan peraturan perundangundangan harus dipastikan memenuhi syarat formil dan materil dengan melibatkan partisipasi masyarakat sebagaimana asas keterbukaan yang merupakan salah satu proses dalam pembentukan peraturan perundanganundangan di Indonesia.

\section{SIMPULAN}

Dalam pembahasan dan hasil penelitian mengenai penerapan asas 
keterbukaan dalam proses pembuatan Undang-Undang Omnibus Law penulis mendapat kesimpulan bahwa, proses pembuatan Undang-Undang Omnibus Law melanggar asas keterbukaan. Karena dalam pembentukan peraturan perundang-undangan harus adanya pemenuhan asas keterbukaan dan partisifasi masyarakat sejak tahap penyusunan, kemudian saat tahap pembahasan di DPR harus dilakukan secara transparan, hatihati dan tidak tergesa-gesa. Berikut juga substansinya harus dipastikan memenuhi syarat materil dan formil pembentukan peraturan perundangundangan sebagaimana telah di atur dalam Undang-Undang Nomor 12 Tahun 2011. Dengan keterbukaan yang memenuhi semua syarat dalam pembentukan peraturan perundang-undangan, membuktikan kepada publik bahwa pemerintah dan DPR dalam membuat Undang-Undang Omnibus Law ini bukan karna kepentingan kelompok atau segelintir elit pengusaha saja, melainkan seluruh masyarakat Indonesia.

\section{DAFTAR PUSTAKA}

Anggono, B. D. (2020) “Omnibus Law Sebagai Teknik Pembentukan Undang-Undang: Peluang Adopsi Dan Tantangannya Dalam Sistem Perundang-Undangan Indonesia," Jurnal RechtsVinding, 9(1), pp. 17-37.

Arham, S. and Saleh, A. (2019) "Omnibus Law Dalam Perspektif Hukum Indonesia,” PETITUM, 7(2 Oktober), pp. 72-81.

Assiddiqie, J. (2014) Perihal Undang-Undang. 3rd ed. Jarkata: RajaGrafindo.

Atmadja, I. D. G. (2018) “Asas-asas hukum dalam sistem hukum," Kertha Wicaksana, 12(2), pp. 145-155.

Attamimi, A. H. S. (1990) "Ilmu Pengetahuan Perundang-Undangan Dan Pengembangan Pengajarannya Di Fakultas Hukum," Jurnal Hukum \& Pembangunan, 20(1), pp. 1-12.

Bahri, S. (2017) “Pengembangan Kurikulum Dasar dan Tujuannya,” Jurnal Ilmiah Islam Futura, 11(1), pp. 15-34.

Barlian, A. E. A. (2016) "Konsistensi Pembentukan Peraturan Daerah Berdasarkan Hierarki Perundang-undangan dalam Prespektif Politik Hukum," FIAT JUSTISIA: Jurnal Ilmu Hukum, 10(4), pp. 605-622.

Bruggink, J. J. H. (1999) Refleksi Tentang Hukum, Citra Aditya Bakti, Bandung. 
KHAZANAH MULTIDISIPLIN

VOL 2 NO 22021

https://journal.uinsgd.ac.id/index.php/kl

Fatanen, A. (2021) "Eksistensi Kewenangan Daerah dalam Perlindungan dan Pengelolaan Lingkungan Hidup Pasca diterbitkannya UndangUndang Cipta Kerja," Khazanah Hukum, 3(1), pp. 1-7.

Febriansyah, F. I. (2016) "Konsep pembentukan peraturan perundangundangan di Indonesia," Perspektif, 21(3), pp. 220-229.

Gani, R. A. (2017) "Dampak dan upaya pemberantasan serta pengawasan korupsi di Indonesia," Justice Pro: Jurnal Ilmu Hukum, 1(2).

Handoyo, B. H. C. (2021) "IDEALISME CONSTITUENDUM MAHKAMAH KONSTITUSI DALAM PENGUJIAN UNDANG-UNDANG TERHADAP UNDANG-UNDANG DASAR,” Arena Hukum, 14(1), pp. 1-18.

Mas, M. (2014) Pemberantasan tindak pidana korupsi. Ghalia Indonesia.

Nugroho, S. A. (2014) Hukum persaingan usaha di Indonesia. Prenada Media.

Qamar, N. et al. (2017) Metode Penelitian Hukum (Legal Research Methods). CV. Social Politic Genius (SIGn).

Sodik, A. A. (2020) "JUSTICIABELEN: Penegakan Hukum di Institusi Pengadilan dalam menghadapi Pandemi Covid-19," Khazanah Hukum, 2(2), pp. 56-64.

Solihah, R. and Witianti, S. (2016) "Pelaksanaan fungsi legislasi Dewan Perwakilan Rakyat pasca pemilu 2014: Permasalahan dan upaya mengatasinya,” Jurnal Ilmu Pemerintahan ISSN, 2442, p. 5958. 